\title{
PHYSICOCHEMICAL AND ENZIMATIC TRANSFORMATIONS OF "EVA" APPLES STORED UNDER MODIFIED ATMOSPHERE
}

\author{
Transformações físico-químicas e enzimáticas de maçãs cv. eva \\ armazenadas sob atmosfera modificada
}

\author{
Ariela Betsy Thomas ${ }^{1}$, Caroline Roberta Freitas Pires ${ }^{2}$, Luiz Carlos de Oliveira Lima ${ }^{3}$
}

\begin{abstract}
The need for a permanent market supply of fresh fruit has generated great interest in postharvest techniques that can promote useful life and quality of the fruit. The aim of this study was to evaluate the efficiency of atmospheric modification using different polymeric films in maintaining postharvest quality and prolonging the shelf life of Eva (Mallus sp) apples. For this, fruits from the city of Barbacena - MG, selected and sanitized were packed in plastic trays and wrapped in the corresponding films. The films used were: polypropylene - $20 \mu \mathrm{m}$, low-density polyethylene - $14 \mu \mathrm{m}$ and high-density polyethylene - $7 \mu \mathrm{m}$. Another group of fruits (control) was not submitted to a modified atmosphere. Subsequently, all the the packages were stored under refrigeration $\left(0^{\circ} \mathrm{C} \pm 0.5\right)$ for 210 days and the evaluations of the following variables were performed every 30 days of storage: hydrogen potential $(\mathrm{pH})$, titratable acidity, soluble solids, weight loss, firmness, total pectin, soluble pectin, pectin methyl esterase and polygalacturonase. The work was conducted in a completely randomized design (4x8), with 4 treatments and 8 experimental times. Each treatment consisted of three replicates and each experimental unit consisted of six fruits. The results were submitted to variance analysis and means were compared by the Tukey test at $5 \%$ probability and regression analysis. The low density polyethylene $(14 \mu \mathrm{m})$ packaging provided the best conservation of the Eva cultivar apple textural characteristics.
\end{abstract}

Index terms: Mallus sp, packaging, firmness, enzymes.

\section{RESUMO}

A necessidade de um abastecimento permanente do mercado com frutas frescas tem gerado um grande interesse em técnicas de conservação pós-colheita que possam promover a extensão da vida útil e da qualidade desses frutos. Objetivou-se, neste estudo, avaliar a eficiência da modificação atmosférica, utilizando diferentes filmes poliméricos na manutenção da qualidade pós-colheita e no prolongamento da vida útil de maçãs "Eva" (Mallus sp). Para tanto, frutos colhidos em Barbacena - MG, selecionados e sanitizados foram acondicionados em bandejas plásticas com seis frutos cada e estas, envoltas nos filmes correspondentes a cada tratamento. Foram utilizados filmes de polipropileno $-20 \mu \mathrm{m}$, polietileno de baixa densidade - $14 \mu \mathrm{m}$ e polietileno de alta densidade $-7 \mu \mathrm{m}$. Um outro grupo de frutos (controle) não foi submetido à atmosfera modificada. Feito isso, as embalagens foram armazenadas em câmara fria $\left(0^{\circ} \mathrm{C} \pm 0,5\right)$ por 210 dias e as avaliações foram realizadas a cada 30 dias de armazenamento, das seguintes variáveis: potencial hidrogeniônico $(\mathrm{pH})$, acidez titulável, sólidos solúveis, perda de massa, firmeza, pectina total, pectina solúvel, pectinametilesterase e poligalacturonase. O trabalho foi conduzido em delineamento inteiramente casualizado (4x8), sendo 4 tratamentos e 8 tempos. Cada tratamento continha três repetições e cada unidade experimental foi constituída por seis frutos. Os resultados foram submetidos à análise de variância e as médias foram comparadas pelo teste de Tukey a 5\% de probabilidade e análise de regressão. A embalagem de polietileno de baixa densidade $(14 \mu \mathrm{m})$ proporcionou a melhor conservação das características texturais das maçãs cv Eva.

Termos para indexação: Mallus sp, embalagem, firmeza, enzimas.

\section{INTRODUCTION}

The interest in the postharvest of fruits has been increasing in recent years in Brazil, because of large harvests, the increase of consumption and the need to permanently supply the market with fresh fruits (Beling, 2004). Refrigerated storage, that consists of temperature and relative humidity control, is the form most used by the apple producing and/or trading companies (Brackmann et al., 2005). However, to enable the long term market supply, refrigeration, alone, is not sufficient, making investments necessary, not only in refrigerated chambers, but in atmospheric modification (MA) as well, that avoids water loss and the natural decomposition of the fruits, maintaining their quality for longer periods (Petri et al., 2011).

The most used method of atmospheric modification is the packaging of the fruits in polymeric films, that possess a relatively low cost and high efficiency, and

\footnotetext{
1Universidade Federal de Lavras/UFLA - Cx. P. 3037 - 37200-000 - Lavras - MG - Brasil - arielabbt@gmail.com

${ }^{2}$ Universidade Federal do Tocantins/UFT - Palmas - Tocantins - TO - Brasil

3Universidade Federal de Lavras/UFLA - Lavras - MG - Brasil

Received in june 05, 2014 and approved in july 14, 2014
} 
the ideal type of packaging is the one which enables the concentration of $\mathrm{O}_{2}$ to be sufficiently low to slow the respiration, however, higher than the concentration critical for the onset of the anaerobic respiration (Chitarra; Prado, 2002). The effects of that $\mathrm{O}_{2}$ reduction and consequent increase of the of $\mathrm{CO}_{2}$ content vary according to the exposure time and the barrier properties of the packaging material, but usually MA reduces the respiration rate and softening of the fruits, delays contamination by microorganisms, can inhibit the ethylene action besides maintaining the nutritional quality of the fruits for longer periods (Kader, 1993; Manolopoulou et al., 2010). High and low density polyethylene films and polypropylene films have been widely used for atmospheric modification of fruits and vegetables (Cruz et al., 2001; Donazzolo et al., 2003; Brackmann et al., 2006; Antmann; Lema; Lareo, 2008).

The cultivar Eva was developed by the Agronomic Institute of Paraná (IAPAR) from the cross between cultivars Gala and Anna (Hauagge; Tsuneta, 1999) and its production has been notable for presenting high yield, quality fruits, resistance to diseases and early maturation. For presenting low coldness requirements, the Eva apple tree is able to produce quality fruits in regions of subtropical climate.

The fruits weigh between 120-160 grams, are sweet, with balanced acidity and high quality, and their harvest occurs usually before the other cultivars, between the months of November and January, that facilitates their commercialization (Pommer; Barbosa, 2009). As a result, efficient storage is also necessary so that the fruits can be marketed with quality together with the later-harvested cultivars.

The texture is an important attribute in the evaluation of fruit quality, being a decisive factor for consumer purchase choice. The firmness is directly associated to the composition and structure of the cell walls, that consist basically of pectin, hemicellulose and cellulose (Zhang et al., 2010), as well as its integrity. Alterations in those structures result from the action of enzymes associated to the cell wall, such as pectin methylesterase, polygalacturonase, $\beta$-galactosidase and cellulase, among others, that act on the pectins and other carbohydrates (Chitarra; Chitarra, 2005), resulting in solubilisation, depolymerisation and rearrangements of their associations, which eventually affect cell wall strength and lead to fruit softening (Goulao; Cosgrove; Oliveira, 2008).

Facing the need for long term storage of Eva apple tree fruits, the purpose of this study was to verify the effect of the use of different polymeric films with atmospheric modification on the quality maintenance during postharvest storage and extension of the useful life of cv. Eva apples.

\section{MATERIAL AND METHODS}

Apples of the Eva cultivar from a commercial orchard in the town of Barbacena, Minas Gerais, picked in December of 2011 were used. The fruits were picked manually and selected for appearance (predominantly reddish, rounded with transversal and longitudinal diameters of approximately $60 \mathrm{~mm}$ ) absence of injuries and decay. Soon afterwards they were washed, sanitized with $100 \mathrm{mg} . \mathrm{L}^{-1}$ sodium hypochlorite for 10 minutes and stored in the different packagings for the atmospheric modification. A completely randomized experimental design $(4 \times 8)$ was used, with four treatments: low density polyethylene-14 $\mu \mathrm{m}$ (LDPE), high density polyethylene-7 $\mu \mathrm{m}$ (HDPE), polypropylene-20 $\mu \mathrm{m}$ (PP) and unwrapped - control) and eight evaluation times $(0,30,60,90,120$, 150,180 and 210 days of storage) with three repetitions per treatment and an experimental unit composed of six fruits. After treatment application, the fruits were stored in a cold chamber $\left(0^{\circ} \mathrm{C} \pm 0.5\right) \pm 90 \%$ humidity.

The soluble solids were determined by refractometry, according to the norms (AOAC, 2000), using a digital refractometer and the results expressed in $\%$. The titratable acidity was obtained by the technique recommended by AOAC (2000), and expressed in malic acid percentage. The $\mathrm{pH}$ was evaluated by glass electrode potentiometry, following the technique of AOAC (2000). The firmness was determined individually in the whole fruit without peel, measures conducted in the equatorial area at two equidistant points, with the aid of a Fruit Hardness TesterModel PTR-300 penetrometer with $5 \mathrm{~mm}$ diameter probe. The results were expressed in Newtons $(\mathrm{N})$.

The fresh mass loss (\%) was calculated by gravimetry, according to the expression: $F M L=(I M-$ SM) $100 / I M$, in which IM is the initial mass and SM the mass of the sample, on the day of the evaluation. The total and soluble pectins were extracted in according to the technique of McCready and McComb (1952), the measure carried out in a Beckman 640B spectrophotometer, at 520 $\mathrm{nm}$, according to the Bitter and Muir (1973) technique. The results were expressed in mg of galacturonic acid per $100 \mathrm{~g}$ of pulp.

The enzymatic extraction of the pectin methylesterase (PME) and polygalacturonase (PG) was carried out according to the technique of Buescher 
and Furmanski (1978). The determination of the pectin methylesterase activity followed the techniques of Hultin, Sun and Bulger (1966). An unit of PME activity was defined as the amount of enzyme capable of catalyzing pectin demethylation corresponding to the consumption of $1 \mu \mathrm{mol}$ of $\mathrm{NaOH}$ per gram of fresh pulp.min. The measure of the polygalacturonase (PG) was conducted according to Markovic, Heinrichová and Lenkey (1975). The enzymatic activity was expressed in $\eta \mathrm{mol}$ of galacturonic acid per gram of pulp per minute.

The Sisvar software (Ferreira, 2011) was used for statistical analysis of the variables. The variance analysis was conducted through the F test, to verify the difference among the treatments. The averages of the treatments, when significant, were compared, by the Tukey test, to $5 \%$ of probability. When significant difference in the interaction among the factors was found, regression analysis was carried out.

\section{RESULTS AND DISCUSSION}

According to the results, it was possible to observe that the soluble solids content was affected by the interaction between the storage time and the different packages (Figure 1).

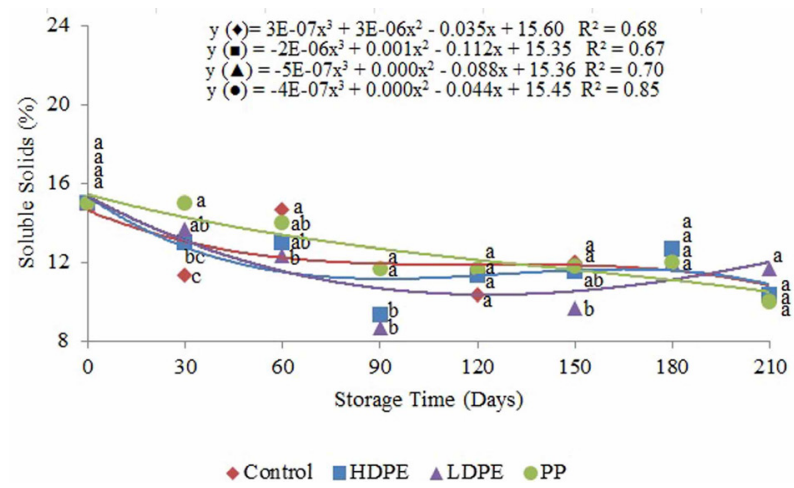

Figure 1 - Modified atmosphere effects on the soluble solids in apples cv. Eva stored for 210 days under refrigeration. Averages followed by the same letter within each time, do not differ among themselves by the Tukey test at $5 \%$.

It was verified that for all the packages there was a decrease in the soluble solids content during the storage period, probably by the use of sugar, organic acids and other soluble solids in the respiration process and metabolism maintenance. After 180 days of storage, the fruits conditioned in the different packages did not present significant differences among themselves. However, these data disagree with those of Rocha, Barreira and Morais 2004, who, in a study with Bravo Esmolfe apples did not detect significant differences in that variable with the use of the modified atmosphere.

The storage time significantly influenced the titratable acidity (TA) of the fruits (Figure 2), with no great variation of this variable along the experimental time. The modified atmosphere did not affect this variable.

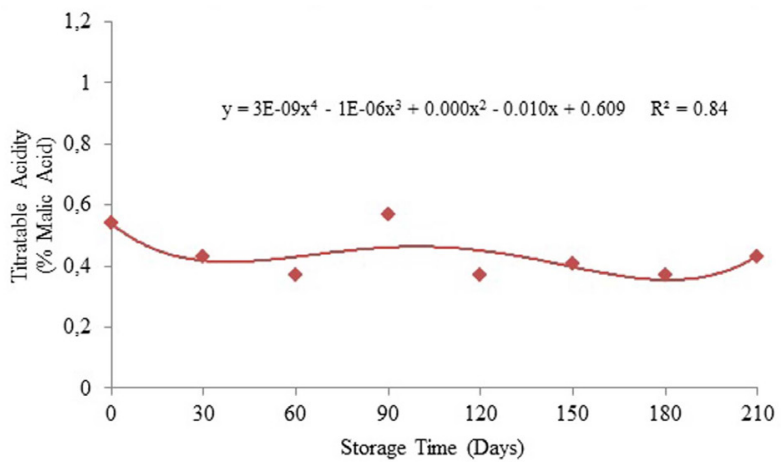

Figure 2 - Apples cv. Eva titratable acidity (TA) stored for 210 days under refrigeration.

The $\mathrm{pH}$ was not affected by the use of the modified atmosphere nor by the storage time, presenting a mean value of 3.55. In a study featuring eight apple cultivars, Delicious, Golden Delicious, Ralls and Fuji among others, Wu et al. (2007) found a mean value of 3.87 for the apple $\mathrm{pH}$. Note that "Eva" has a characteristically lower $\mathrm{pH}$ than others, presenting as more acidic than these other cultivars.

There was a significant effect of the different packages and storage times on fruit firmness, which decreased over the 210 days (Figure 3), presenting about $49 \%$ lower at the end of the experiment.

The highest average was presented by the fruits packed in low density polyethylene (LDPE) (21.63N), being significantly higher than that of fruits packed in polypropylene (PP), which presented an average of $20.37 \mathrm{~N}$. However, there was no difference among the other packages, which showed an average of $20.30 \mathrm{~N}$ for the control fruits and $21.21 \mathrm{~N}$ for those in high density polyethylene (HDPE).

According to Roeck et al., (2008) and Goulao, Cosgrove and Oliveira, (2008) the loss of firmness is attributed mainly to the activity of enzymes responsible for the degradation of the cell wall and Awad (1993) also highlights the loss of water from the cells as a cause of that reduction. Studies such as those of Rocha, Barreira and Morais (2004) 
with Bravo Esmolfe apples and Santana, Benedetti and Sigrist (2010) with "Douradão" peaches (Prunus persica) point out that fruits stored under a modified atmosphere become firmer than those under normal atmosphere.

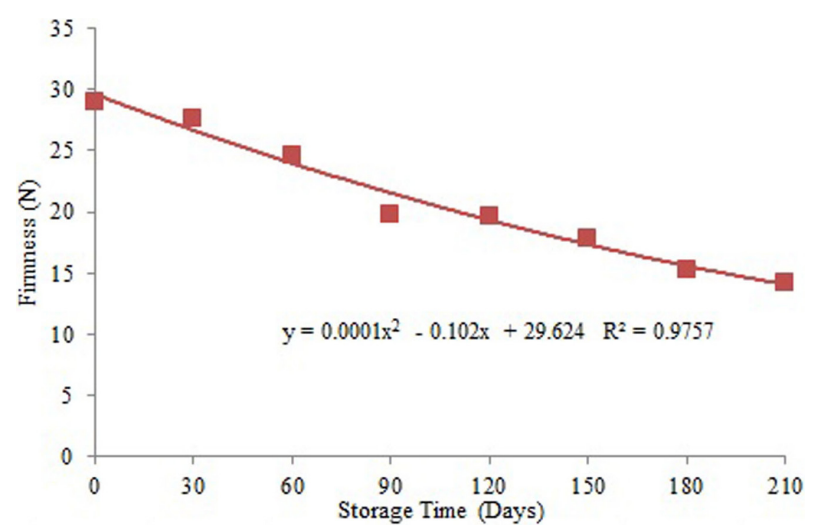

Figure 3 - Firmness of the pulp of Eva apples stored for 210 days under refrigeration.

The weight loss of the apples was influenced by the packaging, storage time and the interaction of packaging and storage period. Figure 4 shows the linear increase of the weight loss during storage for all treatments and from 90 days on, there was a difference, between the control and the other treatments, that persisted until the end of 210 days, showing that the control group fruits had significantly higher values than the other treatments. At the end of the experiment, the fruits stored in HDPE and LDPE showed the lowest mass loss values, being statistically diferent from the other treatments.

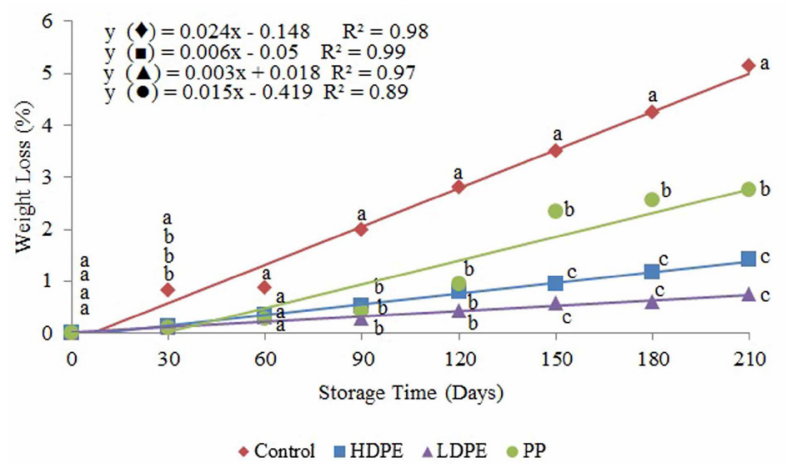

Figure 4 - Effect of modified atmosphere on weight loss of Eva apples stored for 210 days under refrigeration. Averages followed by the same letter within each time, do not differ among themselves by the Tukey test at $5 \%$.
This result is consistent with studies that claim that the use of MA packages, when used properly, can reduce the weight loss (Rocha; Barreira; Morais, 2004). Weight loss in stored fresh fruits may occur due to water eliminated by transpiration (Javanmardi; Kubota, 2006) and metabolic respiration processes. Therefore, fruits stored in low water vapor permeable films tend to maintain the fresh weight longer.

Total pectin was influenced by the different packages and the interaction between packaging and storage time. The fruits of the control group did not differ significantly from the fruits packed in LDPE during storage, showing the highest total pectin averages (Figure 5).

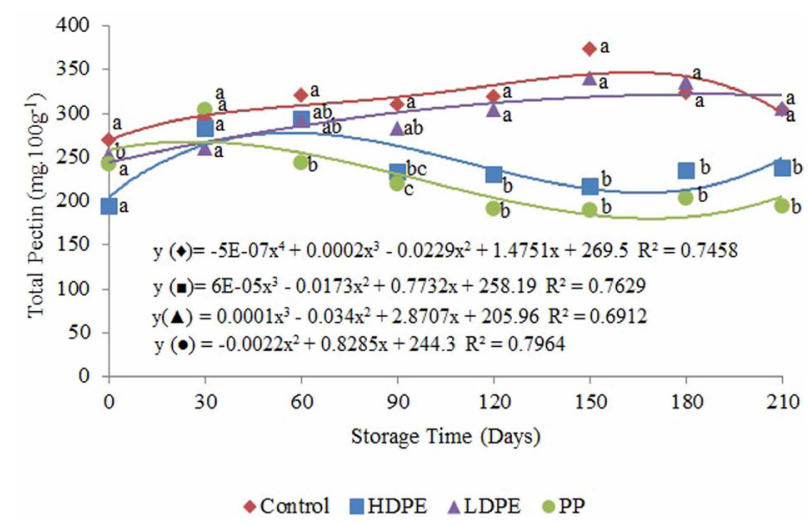

Figure 5 - Effect of modified atmosphere on the total pectin levels of Eva apples stored for 210 days under refrigeration. Averages followed by the same letter within each time, do not differ among themselves by the Tukey test at $5 \%$.

The soluble pectin levels were influenced by packaging, storage period and the interaction between them. The increased solubility of pectic polysaccharides is arguably one of the characteristics associated with fruit ripening (Canteri et al. 2012) however, fruit containing a high percentage of soluble pectin generally has weak texture and is little resistant during transport and storage (Carvalho, 1994). It was also observed that the soluble pectin content increased in fruits in all packages (Figure 6) and after 150 days of storage there was a higher differentiation between fruits in MA and those of the control group; the fruits under LDPE being those which presented the lower average at this time. 


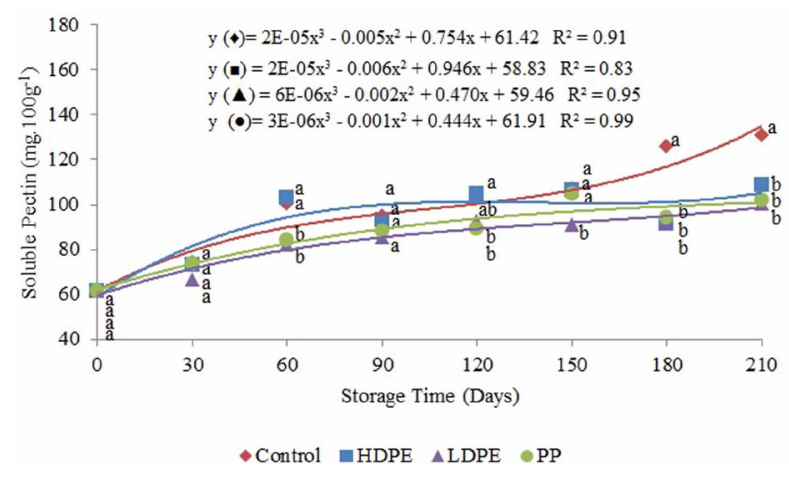

Figure 6 - Effect of modified atmosphere on the soluble pectin levels of Eva apples stored for 210 days under refrigeration. Averages followed by the same letter within each time, do not differ among themselves by the Tukey test at $5 \%$.

At 180 and 210 days of storage, the control group fruits showed the highest levels of soluble pectin, demonstrating the beneficial effect of MA on maintaining a lower content of this variable. The increase in soluble pectin content during ripening of apples was also described by Fischer, Arrigoni and Amado (1994) and Gwanpua et al., (2012). By enzymatic action, the total pectin undergoes demethylation and simplification of its chains, causing the solubility until the total degradation, when the fruit is very ripe (Nunes et al., 2010).

The pectin methyl esterase (PME) was affected by storage time and the interaction between time and packaging. Figure 7 shows that from 180 days on, the fruits in the control group did not differ from those stored in different polymeric films.

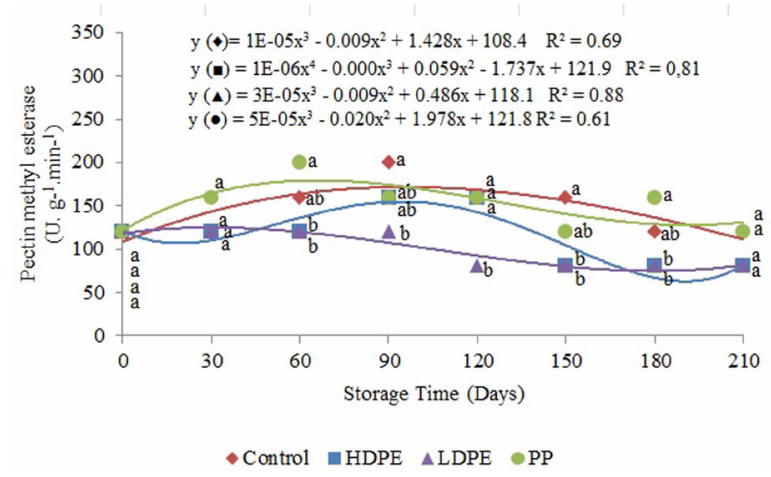

Figure 7 - Modified atmosphere effect on pectin methyl esterase (PME) activity in Eva apples stored for 210 days under refrigeration. Averages followed by the same letter within each time, do not differ among themselves by the Tukey test at $5 \%$.
Some authors have reported that PME only acts as a precursor of $\mathrm{PG}$, provoking the demethylation of the pectins, thus facilitating PG activity (Bennet, Labavitch, 2008). Polygalacturonase (PG) underwent the influence of the different packages, storage time and the packaging $\mathrm{x}$ time interaction. It was possible to observe an increase of the PG activity in fruits packed in HDPE and LDPE up to 120 days, followed by reduction by the end of storage, while for the control group and PP the increase occurred until the end of 210 days (Figure 8). There was no difference among the fruits of the control group compared to those stored in different packages up to 60 days. Fruits packed in LDPE showed the lowest enzymatic activity values from 180 days.

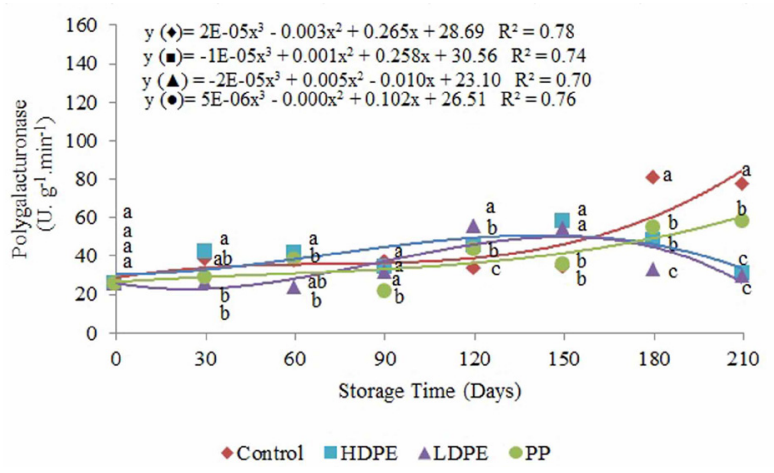

Figure 8 - Effect of modified atmosphere on polygalacturonase (PG) activity in Eva apples stored for 210 days under refrigeration. Averages followed by the same letter within each time, do not differ among themselves by the Tukey test at $5 \%$.

PG was shown to be responsible for the softening that accompany the solubilization of pectins during fruit ripening, but according to Gwanpua, Verlinden and Hertog (2012) firmness loss in apples should not be attributed only to PG activity. The same author reported that in low oxygen concentrations, the synthesis of enzymes that degrades cell wall was lower and contributed to a lower rate of loss of firmness in 'Braeburn' apples.

\section{CONCLUSIONS}

The low density polyethylene packaging provided the best conservation of the textural characteristics of apples cv. Eva with lower polygalacturonase activity and lower mass loss. The use of modified atmosphere did not maintain the soluble solids content during the storage and did not significantly affect the titratable acidity nor the $\mathrm{pH}$. 


\section{ACKNOWLEDGEMENTS}

The authors thank the research funding agencies Fapemig, Capes and $\mathrm{CNPq}$, for the financial support received for this work.

\section{REFERENCES}

ANTMANN, G.; LEMA, P.; LAREO, C. Influence of modified atmosphere packaging on sensory quality of shiitake mushrooms. Postharvest Biology and Technology. 49(2-3):164-170, 2008.

\section{ASSOCIATION OF OFFICIAL ANALYTICAL} CHEMISTS (AOAC). Official methods of analysis of AOAC International. 17.ed. Gaitheersburg, 2000 .

AWAD, M. Fisiologia pós-colheita de frutos. São Paulo: Nobel, 1993. 114p.

BELING, R. R. Anuário brasileiro da fruticultura. Santa Cruz do Sul: Gazeta Santa Cruz, 2004. 136p.

BENNETT, A. B.; LABAVITCH, J. M. Ethylene and ripening-regulated expression and function of fruit cell wall modifying proteins. Plant Science. 175(1-2):130136, 2008.

BITTER, T.; MUIR, H. M. A modified uronic acid carbazole reaction. Analytical Biochemistry. 4(4):330334, 1973.

BRACKMANN, A. et al. Conseqüência da umidade relativa durante o armazenamento refrigerado e em atmosfera controlada na qualidade da maçã 'Gala'. Ciência Rural. 35(5):1197-1200, 2005.

BRACKMANN, A. et al. Uso de filmes de polietileno e absorção de etileno para o transporte refrigerado de maçã 'Gala'. Semina: Ciências Agrárias. 27(3):423-428, 2006.

BUESCHER, R. W.; FURMANSKI, R. J. Role of pectinasterase and polygalacturonase in the formation of woolliness um peaches. Journal of Food Science. 43(1):264-266, 1978.

CANTERI, M. H. G.; MORENO, L.; WOSIACKI, G.; SCHEER, A. P. Pectina: da matéria-prima ao produto final. Revista Polímeros. 22(2):149-157, 2012.
CARVALHO, V. D. de. Qualidade e conservação póscolheita de goiabas. Informe Agropecuário. 17(179): 48-54, 1994.

CHITARRA, M. I. F.; CHITARRA, A. B. Pós-colheita de frutos e hortaliças: fisiologia e manuseio. 2. ed. Lavras: UFLA, 2005. 783 p.

CHITARRA, A. B.; PRADO, M. E. T. Utilização de atmosfera modificada e controlada em frutos e hortaliças. Lavras: UFLA/FAEPE, 2002. 66 p.

CRUZ R. G. et al. Conservação refrigerada de carambolas em embalagens plásticas. Revista Brasileira de Engenharia Agrícola e Ambiental. 5(2), 2001.

DONAZZOLO, J. et al. Utilização de filmes de polietileno de baixa densidade (PEBD) para prolongar a vida pós-colheita de morangos, cv. oso grande.

Ciência e Agrotecnologia. 27(1): 165-172, 2003.

FERREIRA, D. F. Sisvar: a computer statistical analysis system. Ciência e Agrotecnologia. 35(6):1039-1042, 2011.

FISCHER, M.; ARRIGONI, E.; AMADO, R. Changes in the pectic substances of apples during development and postharvest ripening. Part 2: Analysis of the pectic fractions Carbohydrate Polymers. 25(3):167-175, 1994.

GOUlaO, L. F., COSGROVE, D. J., OLIVEIRA, C. $\mathrm{M}$. Cloning, characterisation and expression analyses of cDNA clones encoding cell wall-modifying enzymes isolated from ripe apples. Postharvest Biology and Technology. 48(1):37-51, 2008.

GWANPUA, S. G.; VERLINDEN, B. E.; HERTOG, M. L. A. T. M. Kinetic modeling of firmness breakdown in "Braeburn" apples stored under different controlled atmosphere conditions. Postharvest Biology and Technology. 67(1):68-74, 2012.

HAUAGGE, R.; TSUNETA, M. "IAPAR 75 Eva", "IAPAR 76 - Anabela" e "IAPAR 77 - Carícia" - Novas cultivares de macieira com baixa necessidade em frio. Revista Brasileira de Fruticultura. 21(3):239242, 1999. 
HULTIN, H. O.; SUN, B.; BULGER, J. Pectin methyl esterase of the banana: purification and properties. Journal of Food Science. 31(3):320-327, 1966.

JAVANMARDI, J.; KUBOTA, C. Variation of lycopene, antioxidant activity, total soluble solids and weight loss of tomato during postharvest storage. Postharvest Biology and Technology. 41(2):151-155, 2006.

KADER, A. A. Modified atmosphere storage of tropical fruits. In: KADER, A. A. (Ed.). Postharvest technology horticultural crops. Oakland: University of California, 1993. p. 15-20.

MANOLOPOULOU, $\mathrm{H}$. et al. Modified atmosphere packaging storage of green bell peppers: quality criteria. Biosystems Engeneering. 106(4):535-543, 2010.

MARKOVIC, O.; HEINRICHOVÁ, K.; LENKEY, B. Pectolytic enzymes from banana. Collection

Czechoslovak Chemistry Community. 40(3):769-774, 1975.

MCCREADY, P. M.; MCCOMB, E. A. Extraction and determination of total pectic material. Analytical Chemistry. 24(12):1586-1588, 1952.

NUNES, E. E. et al. Efeito de diferentes temperaturas na qualidade de mandioquinha-salsa minimamente processada. Horticultura Brasileira. 28(3), 2010.
PETRI, J.L. et al. Avanços na cultura da macieira no Brasil. Revista Brasileira de Fruticultura. 33(1):4856, 2011.

POMMER, C. V.; BARBOSA, W. The impact breeding on fruit production in warm climates of Brazil. Revista Brasileira de Fruticultura. 31(2):612-634, 2009.

ROCHA, A. M. C. N., BARREIRA, M.G., MORAIS, A.M.M.B. Modified atmosphere package for apple 'Bravo de Esmolfe'. Food Control. 15(1):61-64, 2004.

ROECK, A. D. et al. Effect of high pressure/high temperature processing on cell wall pectin substances in relation to firmness of carrot tissue. Food Chemistry. 107(4):1225-1235, 2008.

SANTANA, L. R. R.; BENEDETTI, B. C.; SIGRIST, J. M. M. Sensory characteristics of 'Douradão' peaches submitted to modified atmosphere packaging. Revista Brasileira de Fruticultura. 32(3):700-708, 2010.

WU, J. et al. Chemical compositional characterization of some apple cultivars. Food Chemistry. 103(1):88-93, 2007.

ZHANG, L. et al. Changes in firmness, pectin content and nanostructure of two crisp peach cultivars after storage. LWT - Food Science and Technology. 43(1):26-32, 2010. 